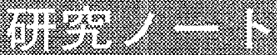

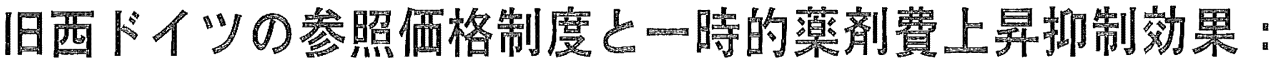 89年の一䝰的な䛨制に寄与したか?}

中 村 洋*

旧西ドイッにおいて参照研格制度が導入された89年に薬剤費総額の上昇は抑制されたが，その後 は以前之同様かそれ以上に上昇している。このことから, 参照価格制度導入の薬剤費上昇抑制効果 は一時的であると論じられている。その楽剤費抑制効果について個別成分レベルで分析した結果, 89年から91年にかけて制度対象になった成分の売上変化率の平均值は, 制度対象外成分のそれに比 べ一時的に有意に低くなったことが判明した。しかし，89年 9 月の制度導入前後のデー夕を分析し た結果, 参照価格制度が89年における薬剂費上昇の一時的な抑制に殆じ寄与していないことが示唆 される。つまり, 参照価格制度は制度対象成分の売上を一時的に低下させたものの, 楽剂費総額の 上昇を抑制するほどの大きな効果は一時的にも存在しなかったと考えられる。

キーワード : 参照価格制度, 一時的薬剂費上昇抑制効果, 個別成分売上

\section{1.はじめに}

現在，10を超える国や地域においてさまざまな 形の参照価格制度が導入されている注1)。その制 度の基本的内容は，薬効，副作用，溶解の程度等 で同等とみなされる医薬品のグループごとに同一 の保険償還上限価格（=参照価格）を設定すると いうあのである。

参照価格制度導入の一つの大きな目的は薬剤費 の上昇抑制にある。そこで関心を集めたのが，他 国に先駆けて参照価格制度を導入した旧西ドイッ における薬剤費への影響である。旧西ドイッでは 89年 9 月に参照価格制度が実施された。公的医療 保険における医薬品の売上高の伸びが89年こそ抑 えら机たのの，その後は以前と同様かそれ以上

*慶應義塾大学大学院経営管理研究科
に上昇している。このことから，参照洒格制度の 薬剂費上昇抑制効果は一時的でしかないと議論さ れている（日本製薬団体連合会，1997；Dickson and Redwood, 1998 ; 铇田・南部, 1999)。

本研究の第 1 の目的は，旧西ドイッにおける参 照価格制度の薬剤費上昇抑制効果を個別成分レベ ルで分析することである。制度対象成分の売上变 化率の平均值と制度対象外成分のそれを，参照価 格設定直後と数年後の時期に分けて比較する。上 記に挙げた既存文献は，マクロデータから参照価 格制度の一時的な薬剤費抑制効果を示唆したが,

†本研究作成において，児玉俊介教授，田中滋教授， 加賀山祐樹氏，鈴木雅人氏，レフェリーの方より大 変貴重なコメントを頂いた。ここに感謝の意を表し たい。しかし，論文の誤りの責任は筆者にあること は言うまでもない。本研究は, 医楽産業政策研究所 と医療科学研究所加らの助成を受けた。

注 1 ）例えば, Dickson and Redwood（1998）参照。 
本研究ではその一時的効果がミクロデータから検 証可能かどうかを分析する讷2)。ミクロデータを 扱った参照価格制度関連文献としては，鈴木・中 村（1998）がある。しかし，その研究は制度対象 医薬品の価格之処方量への影響を調べたものであ り，売上への影響を明示的に分析していない。ま た，制度対象成分と対象外成分を区別した検定む 行われていない。

第 2 の目的は，89年に観察された一時的な薬剤 費上昇鈍化が，参照価格制度の影響によるものか どうかを分析することである。89年に導入された のは参照価格制度だけではない。その制度が実施 される以前の同年 1 月に，包括的な医療保険改革 法 (Gesundheitsreformgesetz：GR G) が施行 されており，参照価格制度はGRGの一部にしか すぎない。その他に導入された主な政策として, 参照価格制度対象外医薬品の自己負担額の引き上 げ，経済性審查導入，薬剤師による薬剤代替調剂 制度が挙げられる。以下では，参照価格制度が89 年に抢ける薬剤費上昇の一時的な抑制によ゙の程度 寄与したのか，医療保険改革法のその他の政策は その一時的な抑制に影響を及ぼしているのかどう かを考察する。以下では，薬剤費上昇が参照佂格 制度導入の89年に一時的に抑制されたことを理由 に，その一時的抑制が参照価格制度の導入によっ て引き起こされたと結論づけることに問題がある ことを指摘する。この指摘は, 上記の既存研究の 結論とは異なる。参照価格制度がその鈍化に殆ど 寄与していないとすれば，これまで議論されてき た一時的な楽剤費上昇抑制効果が存在したとして も，その影響は小さいということになる。

現在，日本においてあ，ドイッの参照佂格制度 を基に，同等とみなされる医薬品グループに同一 保険償還上限佂格を設定することが議論されてい る。ドイッの参照価格制度では, 医薬品の購入価

注 2 ）上記の文献では, 参照価格制度の一時的な薬剂 費抑制効果についての検証は行われていない。
格が参照価格を超えた場合，その超過額を患者が 負担する。日本に求いては，その超過額が発生し ないように購入価格を参照価格以下に制限するこ とが提案されている注3)。ただ，旧西ドイッにお いても患者の超過額の自己負担は殆ど発生しなかっ たことから，日本で検討されている制度とドイッ の制度には実質的な違いはない。したがって、ド イッ型参照価格制度の薬剤費への影響についてよ り詳細な分析を行うことは，その制度についての 理解を深めるたけでなく，日本における今後の政 策議論上においてあ必要である。

本研究の構成は以下の通りである。第2節では, 旧西ドイッにおけるデータの分析から参照価格制 度が薬剂費上昇抑制によ゙のような影響を与えたか を個別成分レベルで考察する。第 3 節では，参照 価格制度が89年の一時的な薬剤費上昇抑制に殆ど 寄与していないことを示唆する。また，その薬剤 費上昇抑制をあたらした要因について議論する。 第 4 節では，まとめと留意すべき点への言及が行 われる。

\section{2. 参照価格制度の制度対象成分の売上へ の影響 : 個別成分レベルでの分析}

旧西ドイッにおいて，参照価格制度が制度対象 成分の売上に有意な影響を与えたのかぞうかを， 個別成分レベルで分析する。ここでは，制度対象 になった時期別に対象成分の売上合計の変化を概 観した後，参照価格が設定された年の影響とその 後の影響に分けて分析を行う。

旧西ドイッにおける成分処方量。売上のデー夕 はArzneiverordnungs-Reportから入手した。93 年に施行された医療構造法 (Gesundheitsstrukturgesetz：G S G）の影響を極力取り除くため, 92年までのデー夕を使用する。

注 3 ）例えば, ラージュ（99年 5 月10日号）を参照。 
図 1 参照価格制度導入後の売上推移 : 制度導入時期別（制度導入年の売上を 1 に基準化）
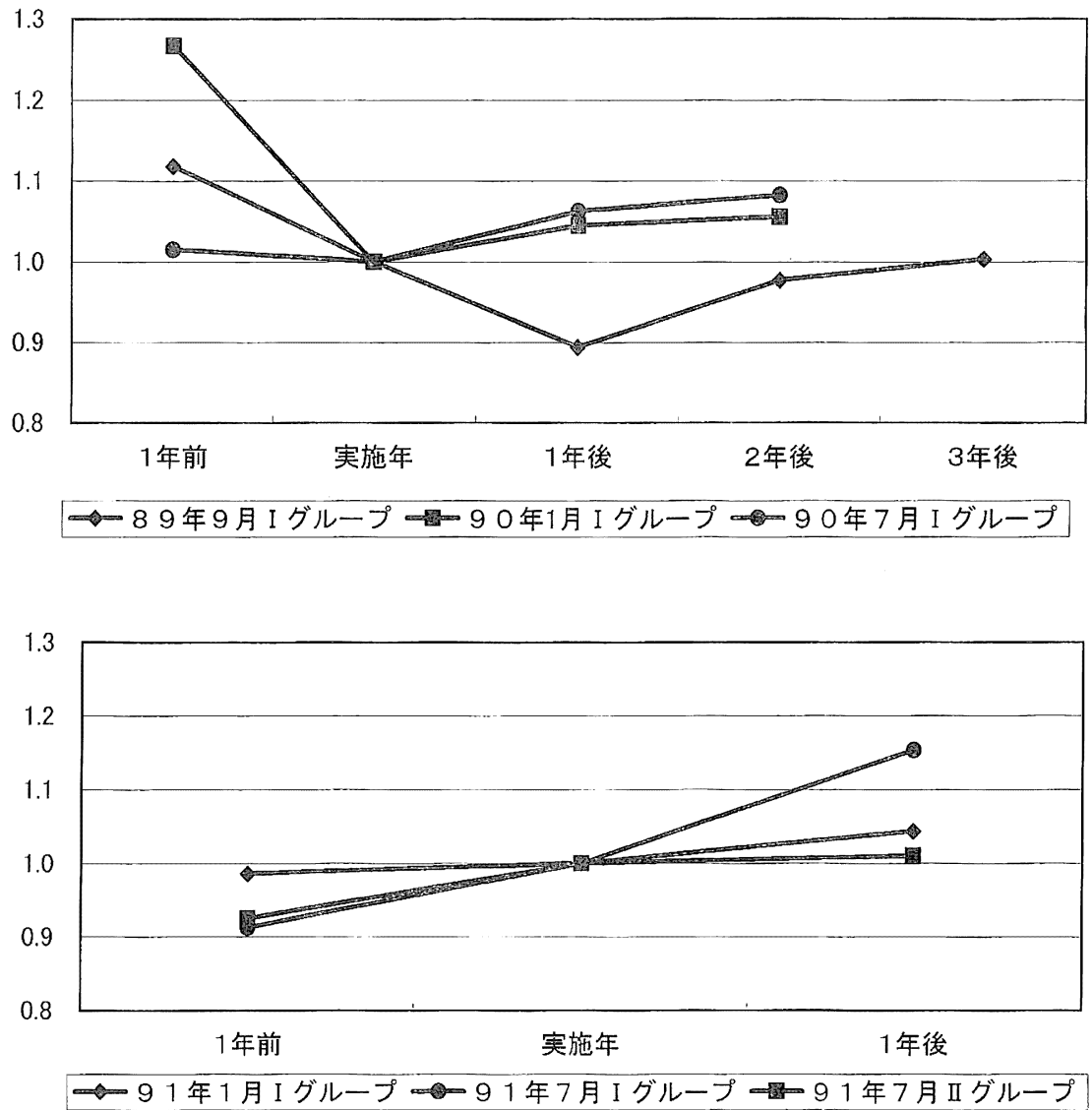

注 1: Arzneiverordnungs-Report (1988-93)より作成。

注2：レベル I の成分に関しては、制度対象 1 年前から $1 \sim 2$ 年後に処方量が5万件を超える成分の データのみを使用した。このことから、91年1月に制度の対象になったAtenololのデータは 使用されていない。

注3：91年7月に制度の対象になったレベル川の医薬品に関しては、旧西ドイツ国内の売上上位 2干品目に入る医薬品の売上を合計した数値を使用した。また、そのグループ内の医薬品の Halcionに異常な副作用が報告されて92年にその売上が約半分に急減したことから、その影響を 排除するため、Halcionの売上とHalcionとある程度の代替関係にあるLendormin（同一グループに 属しHalcionと同様に効果持続時間が短いBenzodiazepin系医薬品)の売上を除くグループ売上 合計とその変化率を計算した。

（1）参照価格制度対象成分の売上変化の概観

最初に，参照佂格制度の対象成分の売上変化を 概推する。図 1 は，制度対象になった時期別に対 象成分の売上合計の変化を表している。ここで, 制度の対象になった年の売上合計を 1 と基準化し ている。

89年に制度の対象になった成分の売上合計は,
対前年比で低下している。制度導入 1 年後の90年 には売上合計がさらに低下した。しかし， 2 年後 の91年には売上合計が上昇に転じている。90年に 制度の対象になった成分の壳上合計も，前年の89 年の売上合計に比べ低下しているが， 1 年後に売 上は上昇に転じている。91年に制度刘象になった 成分の売は:合計は，1 年後の92年のみならず91年 
表 1 売上上畕成分の割合（\%）：制度対象時期別

\begin{tabular}{|l|l|r|rrrr|}
\cline { 3 - 6 } \multicolumn{2}{l|}{} & $\begin{array}{c}\text { 調査対象 } \\
\text { 成分数 }\end{array}$ & 1989 & 1990 & 1991 & 1992 \\
\hline 1989年9月 & レベル I & 10 & 10 & 0 & 90 & 60 \\
1990年1月 & レベル I & 5 & - & 0 & 60 & 80 \\
1991年7月 & レベル I & 28 & - & 25 & 43 & 46 \\
1991年7月 & レベル I & 30 & - & - & 17 & 57 \\
1991 年7月 & レベル I & 7 & - & - & 100 & 67 \\
\hline
\end{tabular}

注 1: Arzneiverordnungs-Report (1988-92)より算出。

注2: レベルIの成分に関しては、制度対象1年前から1〜2年後に処方量が5万件を超える成分の データのみを使用した。このことから、91年1月に制度対象になったAtenololのデータは 使用されていない。

注3：91年7月に制度の対象になったレベルエの医薬品に関しては、旧西ドイツ国内の竞上上位 2千品目に入る医薬品の売上を合計した数值を使用した。

においても増加している注4)。

制度対象成分のうち，どのくらいの成分の売上 が上昇しているのかを示したのが表 1 である。こ の表では，制度の対象になった時期別に，対前年 比で売上が上昇した成分の割合を示している。例 えば，89年 9 月に制度対象になった10成分のうち, 10\%にあたる 1 成分が89年に対前年比で売上を上 昇させている。翌90年には対89年比で売上を増加 させた成分はなかったが，91年においては対90年 比で90\%にあたる9成分が売上を増加させている。 この表から，制度対象直後において売上上昇成分 の割合は小さかったが， $1 \sim 2$ 年以内に多くの成 分の売上が上昇に転じていることがわかる。91年 7 月に制度対象になった成分は，対象直後の91年 にも多くの成分が売上を伸ばしている。

このような売上变化が処方量の変化によるあの 加処方 1 回当たりの価格の変化によるものかを示 したのが図 2 である。この図は制度対象時期別に 制度対象成分の売上合計の対前年変化率と，その 要因分析（処方 1 回当たりの価格变化要因と処方

注 4 ）ただし，91年1月に対象になった成分のなかで， 91年に約650\%売上が上昇したTroxerutinを除 けば，その91年の売上合計は対 90 年比でむしろ 減少している。しかし，Troxerutinを除いた場 合でも，92年の売上合計は対 91 年比で上昇して いる。
量変化要因）の結果をプロットしている。図 2 か ら，制度の対象になった年において売上が低下し た場合には洒格変化要因が大きく寄与しているこ とが読み取れる(i:5)。例えば，90年 7 月に制度対 象になった成分の 90 年における売上合計は対前年 比で1.5\%低下したが，そのうち価格低下要因が1 1.5\%になっている。一方，制度の対象になった 年の $1 \sim 2$ 年後には, その価格低下の影響が縮小 するか消滅し, 処方量上昇が売上増加に寄与して いることがわかる往6)。

以上の分析から，(1)参照価格制度の対象になっ た直後には，洒格要因により売上が低下すること があった, (2)参照価格導入後 $1 \sim 2$ 年後には, 価 格低下要因は縮小あるいは消滅し，処方量の伸び にす支えられて壳上が上昇する，(3)参照価格制度 の対象になった直後であ，売上が上昇する成分が 多く存在する、ことが明らかになった。したがっ て, 参照価格制度導入の制度対象成分の売上への マイナスの影響は一時的であり限定的であること が示唆される。

注 5 ) 制度の対象になった年において売上が低下した のは, 89年と90年に制度の対象になったグルー プである。

注 6 ）91年 7 月に制度の対象になったグループでは, 直後の91年に抒いても全体的に見て洒格变化は 売上上昇要因となっている。 
旧西ドイッの参照佂格制度と一時的薬剤費上昇抑制效果

\section{（2）参照価格制度対象成分亡対象外成分の比較}

次に，参照価格制度が制度対象成分の売上に有 意な影響をむたらすのかどうかを，参照価格が設 定された年の影響とその後の影響に分けて分析を 行う。

93年に施行されたG S G の影響を極力取り除く ため，92年までのデー夕を使用する。分析対象を， 以下の 2 つの理由によりレベル I の制度対象成分 に絞る。第 1 に，日本に拈いて同一成分ごとに同
一保険償還上限価格を設定することが主に議諭さ れている。第 2 に、レベルாのグルーピングが最 初に行われたのは91年 7月であることから，92年 までのデータでは参照価格設定直後とその後の影 響を正確に区別して分析することができない。な ぜなら、レベルIIのグルーピングの対象になった 成分は，92年 6 月まで参照価格以上の医薬品の価 格が対前年比で低下するためである。

分析対象となるレベル I の制度対象成分の中で,

図 2 制度対象時期別の売上変化率とその要因分解（88年～92年）

89年9月に制度対象になった成分(レベル I )の売上合計の変化と要因分析

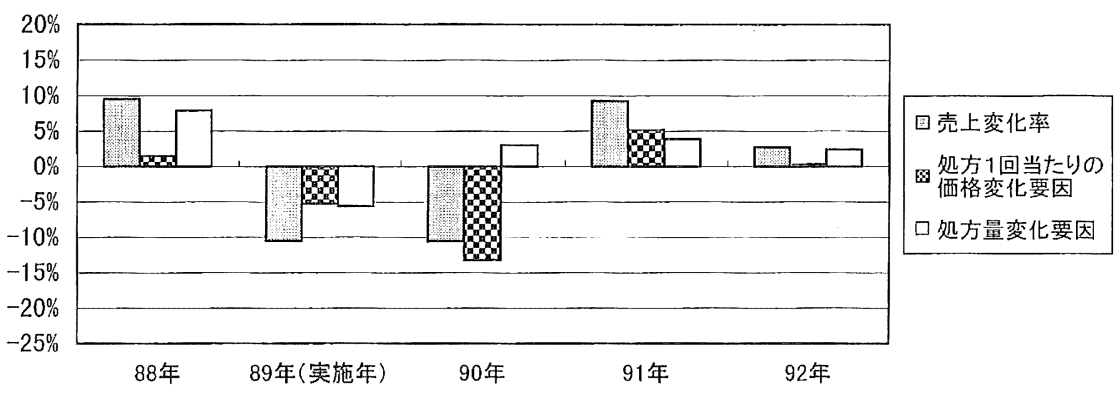

90年1月に制度対象になった成分(レベル I )の売上合計の変化と要因分析

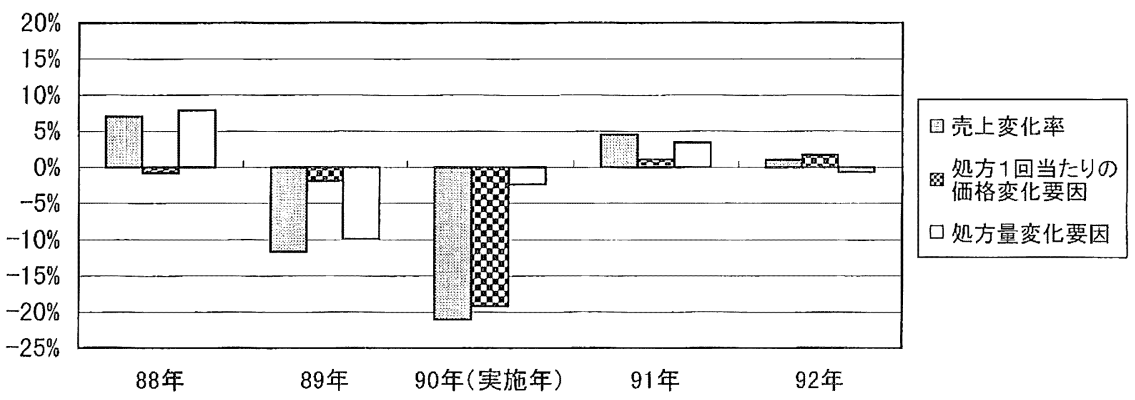

90年7月に制度対象になった成分(レベル I)の売上合計の変化と要因分析

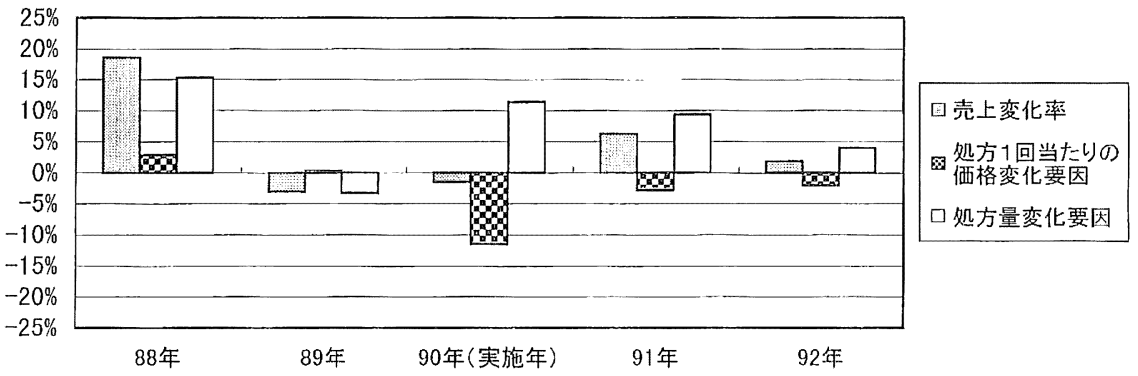


図 2 の続き

91年1月に制度対象になった成分(レベル I )の売上合計の変化と要因分析

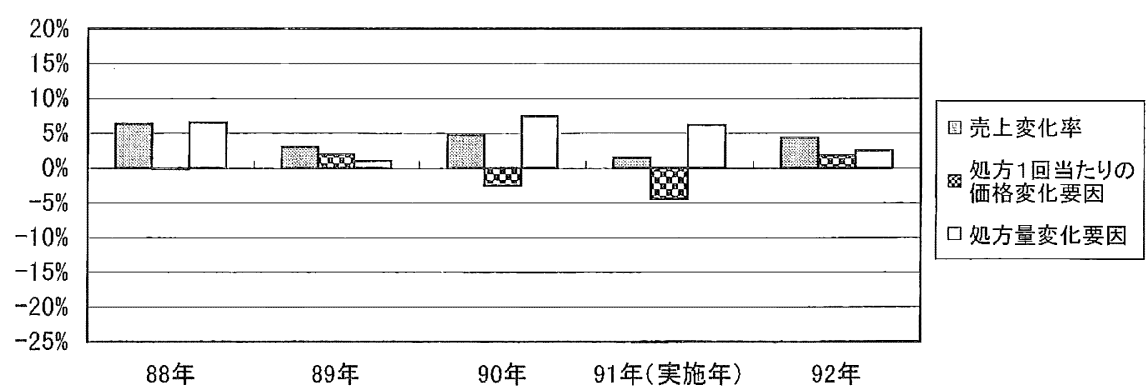

91年7月に制度対象になった成分(レベル I )の売上合計の变化と要因分析

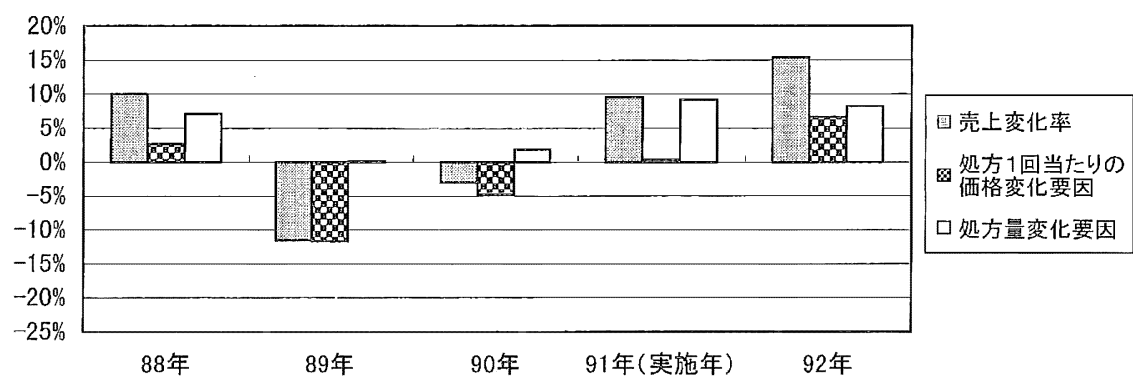

91年7月に制度対象になった成分(レベルI)の売上合計の変化と要因分析

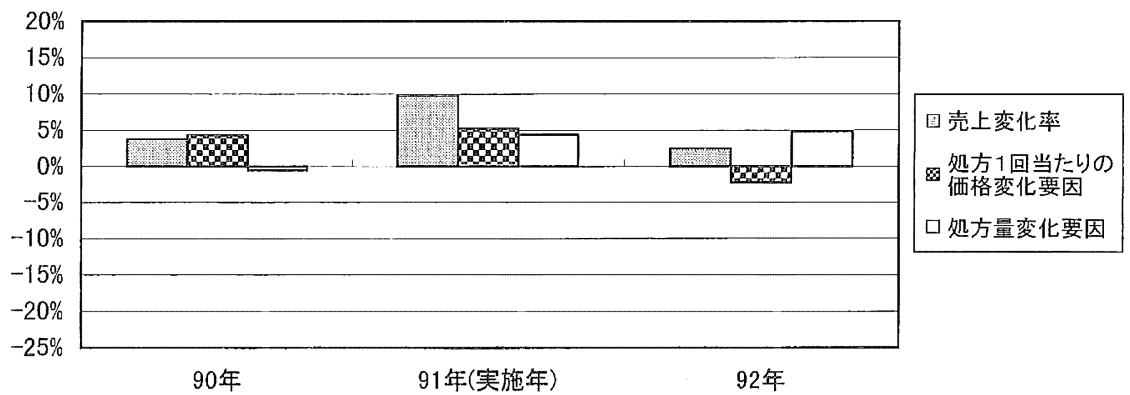

注 1: Arzneiverordnungs-Report (1988-93)より作成。

注2：レベル I の成分に関しては、制度対象 1 年前から1〜2年後に処方量が5万件を超える成分の データのみを使用した。このことから、91年1月に制度の対象になったAtenololのデータは 使用されていない。

注3: 91 年7月に制度の対象になったレベル II医薬品に関しては、旧西ドイツ国内の売上上位 2干品目に入る医薬品の売上を合計した数値を使用した。

比較的にデー夕数が多い 89 年 9 月, 90 年 7 月, 91 年 1 月の制度対象成分を取り上げる(æ7)。その比 較の対象として，制度対象外成分の個別デー夕を 使う。制度の対象として特許切れで売上が比較的
多い成分が選ばれたことから，制度対象外成分も 特許切れで売上上位の成分を取り上げる主8)。 
表 2 参照価格制度対象成分と制度対象外成分の比較 : 参照価格設定の年の影響（旧西ドイッ）

\begin{tabular}{|c|c|c|c|}
\hline & $\begin{array}{c}\text { 売上 } \\
\text { 有意確率 } \\
\text { (片側検定) }\end{array}$ & $\begin{array}{c}\text { 処方昜 } \\
\text { 有意確率 } \\
\text { (再側検定) }\end{array}$ & $\begin{array}{c}\text { 跙格 } \\
\text { 有確率 } \\
(\text { 片側検定) }\end{array}$ \\
\hline \multicolumn{4}{|l|}{$\begin{array}{l}\text { 89年9月制度対象成分 v.S. } \\
\text { 制度対象外成分: } 1989 \text { 年 }\end{array}$} \\
\hline 対象外売上上位 50 成分 & $0.00^{* *}$ & $0.03^{* *}$ & $0.00^{* *}$ \\
\hline 対象外売上上位 100 成分 & $0.00^{* *}$ & 0.41 & $0.00^{* *}$ \\
\hline 対象外売上上位200成分 & $0.00^{* *}$ & 0.19 & $0.00^{* *}$ \\
\hline \multicolumn{4}{|l|}{$\frac{90 \text { 年7月制度対象成分 v.s. }}{\text { 制度対象外成分: } 1990 \text { 年 }}$} \\
\hline 対象外売上上位 50 成分 & $0.04^{* *}$ & 0.93 & $0.00^{* *}$ \\
\hline 対象外売上上位 10 & $0.02^{* *}$ & 0.79 & $0.00^{* *}$ \\
\hline 对象外売上上位 200 成分 & $0.01^{* *}$ & 0.20 & $0.00^{* *}$ \\
\hline \multicolumn{4}{|l|}{$\begin{array}{l}\text { 91年1月制度対象成分 v.s. } \\
\text { 制度対象外成分: } 1991 \text { 年 }\end{array}$} \\
\hline 対象外売上上位 50 成分 & $0.00^{* *}$ & $0.00^{* *}$ & $0.00^{* *}$ \\
\hline 対象外売上上位 100 成分 & $0.00^{* *}$ & $0.01^{* *}$ & $0.00^{* *}$ \\
\hline
\end{tabular}

注1： **(*)は5\%(10\%)水準で有意な差がないという帰無仮説を亲却する。

注2: 2つの標本の分散は等しくないと仮定した。

注3: Arzneiverordnungs-Report (1989-92)より算出。

注4：91年1月の制度対象成分のうち、91年に売上を約650\%增やした Troxerutinは分析から除いた。

\section{a ．参照価格設定直後の影響}

まず，参照佂格が設定された年における制度対 象成分の売上への影響を分析する。具体的には, 制度対象成分の売上変化率の平均值之, 制度対象 外成分の売上変化率の平均値に有意な差があるか どうかを検定する。帰無仮説と対立仮説は以下の ように設定した。

㷌無作説 $: S_{t}^{\text {対象 }}(T=t)=S_{T}$ 刘象外 $^{*}(T)$ 対立仮説 $: S_{t}$ 刘象 $(T=t)<S_{T}$ 刘象外 $i^{*}(T)$

注 7 ）91年 7 月に制度対象になったレベル I の成分は 分析に対象から外した。それらの成分は 92 年 6 月まで参照洒格以上の医薬品の価格が対前年比 で低下するため，参照仙格設定直後之その後の 影響を正確に区別して分析するには92年までの データでは不十分である。

注 8 ) 例えば，Scrip（89年2月1日号）を参照。以下 に導汃れる結論は，制度対象外成分として特許 切れで処方量上位の成分を取り上げても成立する。
ここで， $S_{t}^{\text {䅟 }}(T=t)$ は， $t$ 期に参照価格制度の 対象になった成分の $T$ 期における対前年度比売 上変化率の平均值を表す。 $S_{T}$ 対卦 $(T)$ は， $T$ 期末 までに制度の対象にならなかった成分のうち売上 上位 $i$ 成分の $T$ 期に打ける対前年度比売上变化率 の平均值を表す。参照価格が設定された年に抢け る影響を分析するので， $T=t$ とする。対立仮説 を，制度対象成分の売上変化率の平均值は制度対 象外の壳上变化率の平均值より低い上設定し, 片 側検定を行う。

その分析結果が表 2 に示されている。例えば, 89年に制度対象になった成分の同年における対前 年比売上変化率の平均值之制度対象外成分の上位 50品目のそれとを比較した場合，有意な差がない という帰無仮説が $5 \%$ の有意水準で棄却された。 制度対象外成分の数を増やしても，90年以降に制 度の対象になった成分に関して検定を行っても， 同様な結果が得られた。 
表 3 参照価格制度対象成分亡制度対象外成分の比較：参照価格設定前（旧西ドイツ）

\begin{tabular}{|c|c|}
\hline & $\begin{array}{c}\text { 売上 } \\
\text { 有意確率 } \\
\text { (両側検定) }\end{array}$ \\
\hline \begin{tabular}{|l} 
89年9月制度対象成分 V.s. \\
制度対彩外成分: 1988 年
\end{tabular} & \\
\hline 対象外売上上位 50 成分 & 0.140 \\
\hline 対象外売上上位 100 成分 & 0.468 \\
\hline $\begin{array}{l}\text { 90年7月制度対象成分 v.s. } \\
\text { 制度刘皱外成分: } 1988 \text { 年 }\end{array}$ & \\
\hline 対象外売上上位 50 成分 & 0.512 \\
\hline 対象外売上上位 100 成分 & 0.825 \\
\hline $\begin{array}{l}\text { 90年7月制度対象成分 v.s. } \\
\text { 制度対像外成分: } 1989 \text { 年 }\end{array}$ & \\
\hline 対象外売上上位 50 成分 & $0.005^{* *}$ \\
\hline 対象外売上上位 100 成分 & $0.009^{* *}$ \\
\hline $\begin{array}{l}\text { 91年1月制度対象成分 V.s. } \\
\text { 制度刘解外成分: } 1989 \text { 年 }\end{array}$ & \\
\hline 対象外売上上位50成分 & 0.846 \\
\hline 対象外売上上位 100 成分 & 0.517 \\
\hline
\end{tabular}

\footnotetext{
注1： **(*)は5\%(10\%)水準で有意な差がないという帰無仮説を棄却する。

注2: 2つの標本の分散は等しくないと仮定した。

注3: Arzneiverordnungs-Report (1989-92)より算出。

注 4：制度対象外成分のうち、88年に売上を約 $230 \%$ 増やした

Glyceroltrinitratは分析から除いた。

注5：90年7月の制度対象成分に関し、その売上变化率の平均値は制度対象外の

売上変化率の平均值より低いと設定し、片側検定を行うと、その有意確率は

比較した対象外成分の数にかかわらず、1\%以下であった。
}

比較のため，制度対象成分が制度の対象になる 前に対象外成分と売上变化率に差があったのかど うかを両側検定した。その結果が表 3 に示されて いる。この表汃らは, 多くの場合において，制度 導入前に制度対象成分之対象外成分の売上変化率 に差がないことがわかる。90年 7 月に制度対象に なった成分と対象外成分を89年デー夕を使って検 定した場合のみ，有意な差がないという帰無仮説

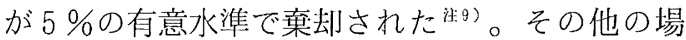
合では，5\%の有意水準では棄却できなかった。

次に，その売上への影響が好方量への影響を通 じたものか，価格への影響を通じたものかを考察 する。まず，参照価格制度が制度対象成分の処方
量によ゙のような影響を与えたのかに注目する。こ こでは，制度対象成分の処方量変化率の平均值之 制度対象外成分のそれとに有意な差があるかどう かを同様の手法で検定した壮10)。

注 9）90年 7 月の制度対象成分に関し，その売上変化 率の平均值は制度対象外の売上変化率の平均値 より低いと設定して，片側検定も行った。そし て, 制度導入直後之同様に, 制度導入前にも制 度対象成分の売上変化率が制度対象外成分のそ れよりあ有意に低いという結果が得られた。有 意確率は比較した対象外成分の数にかかわらず, 1\%以下であった。しかし，その結果は，参照 価格制度の導入が制度対象成分の売上に悪影響 を与えていないという結諭には結びつかない。 
旧西ドイッの参照価格制度と一時的薬剂費上昇抑制効果

検定結果は表 2 に示されている。時期により, あるいは制度対象外成分数により, 異なった結果 が得られる。例えば，89年に制度対象になった成 分と制度対象外成分の上位50品目を比較した場合, 有意な差がないという帰無仮説が $5 \%$ の有意水準 で棄却された。一方，90年 7 月に制度対象になっ た成分と制度対象外成分の上位 100 品目を比較し た場合，有意な差がないという帰無仮説が10\%の 有意水準でも菓却されなかった。したがって，参 照価格制度が制度対象成分の処方量に影響を与え たとは断定できない。

参照価格制度が制度対象成分の処方 1 回当たり の価格に与えた影響に関しては，より明確な結果 が得られる望11。制度対象成分の価格変化率の平 均值と制度対象外成分のそれとに有意な差がある かどうかを同様の手法で検定した。その結果が, 表 2 に示されている新2)。制度対象時期, 制度対 象外成分数にかかわらず，有意な差がないという 帰無仮説が $5 \%$ の有意水準で㶳却された。

これまでの検定結果より, 参照価格制度は, 処 方量よりあ価格への影響を通じて, 制度対象成分 の売上にマイナスの影響を与えたことが示唆され る。

\section{b . 参照価格設定数年後の影響}

次に, 参照価格制度が導入されて数年後の影響 を考察する。例えば，89年に制度の対象になった 成分の91年における対前年比売上变化率の平均值 と，91年末まで制度対象になっていない成分のう ち売上上位成分のそれとを比較する ${ }^{\text {汭 } 13}$ 。畄無仮

注10）対立仮説を, 制度対象成分の処方量変化率の平 均値は制度対象外のそれと異なると設定し, 両 側検定を行った。

注11）各成分の処方 1 回当たりの価格は売上を処方量 で割ることで算出した。

注12）対立仮説を, 制度対象成分の価格变化率の平均 值は制度対象外のそれより低いと設定し, 片側 検定を行った。
説と対立仮説を以下のように設定した。

帰無仮説 $: S_{t}^{\text {対象 }}(T>t)=S_{T}^{\text {刘象外 } i}(T)$

対立仮説 $: S_{t}^{\text {刘象 }}(T>t)<S_{T}^{\text {刘象外 }}(T)$

参照価格が設定された後の影響ということで, $T>t$ となる。分析の結果は表 4 に示されている。 89年に制度の対象になった成分と制度対象外成分 の比較を91年のデータを使って行ったところ, 売 上变化率の平均值に有意な差が認められた。しか し, 翌年の92年のデータでは, 有意な差は認めら れなくなった。90年 7 月と91年 1 月に制度の対象 になった成分の 92 年における売上変化率の平均值 に関しても, 制度対象外成分のそれとの間に有意 な差は認められなかった。

表 2 と表 4 から, 参照価格制度導入が制度対象 成分の売上に，一時的にしかマイナスの影響を与 えないことが個別成分レベルにおいて示唆され る ${ }^{\text {i(14) }}$ 。一時的である理由として, 参照価格以上 の医薬品が参照価格まで一度值下げすると，その 後は更なる值下げ圧力が働かないことが考えられ る。ただ，参照価格という上限価格の存在のため 制度対象成分の価格上昇は制度対象外成分のそれ より制限されることから，制度対象成分と制度対 象外成分の価格変化率の平均值に有意な差の存在 を示唆する検定結果が得られた（表 4 参照）注15)。 しかし, 売上変化率の平均に有意な差をむたらす

注13）ここでは，90年のデー夕を使った比較は行わな かった。なぜなら，89年 9 月の制度対象成分は 90 年 8 月まで参照価格以上の医薬品の価格が対 前年比で低下するため，90年のデータでは参照 価格が設定された年の影響とその後の影響を適 正に区別できないからである。

注14）この結論は, 制度対象外成分として特許切れで 処方量上位の成分を取り上げても成立する。

注15）有意な差が存在しないという帰無仮説は， $5 \%$ の有意水準でほぼ棄却した。一方, 処方量に関 しては, 制度対象成分之制度対象外成分の処方 量変化率の平均值に有意な差の存在があるとい う帰無仮説を $5 \%$ の有意水準では裹却できなかった。 
表 4 参照価格制度対象成分と制度対象外成分の比較：数年後の影響（旧西ドイツ）

\begin{tabular}{|c|c|c|c|}
\hline & $\begin{array}{c}\text { 売上 } \\
\text { 有意確率 } \\
\text { (片側検定) }\end{array}$ & $\begin{array}{c}\text { 処方量 } \\
\text { 有意確率 } \\
\text { (两側検定) }\end{array}$ & $\begin{array}{c}\text { 価格 } \\
\text { 有意確率 } \\
\text { (片側検定) }\end{array}$ \\
\hline \multicolumn{4}{|l|}{$\begin{array}{l}\text { 89年9月制度対象成分 v.s. } \\
\text { 制度対象外成分: 1991年 }\end{array}$} \\
\hline $\begin{array}{l}\text { 対象外売上上位 } 50 \text { 成分 } \\
\text { 対象外売上上位 } 100 \text { 成分 }\end{array}$ & $\begin{array}{l}0.011^{* *} \\
0.036^{* *}\end{array}$ & $\begin{array}{l}0.053^{*} \\
0.105\end{array}$ & $\begin{array}{l}0.155 \\
0.017^{* *}\end{array}$ \\
\hline \multicolumn{4}{|l|}{$\begin{array}{l}\text { 89年9月制度対象成分 v.s. } \\
\text { 制度対象外成分: } 1992 \text { 年 }\end{array}$} \\
\hline 対象外売上上位50成分 & 0.644 & 0.458 & $0.019^{* *}$ \\
\hline 対象外売上上位 100 成分 & 0.445 & 0.172 & $0.004^{* *}$ \\
\hline \multicolumn{4}{|l|}{$\begin{array}{l}\text { 90年7月制度対象成分 v.s. } \\
\text { 制度対象外成分: 1992年 }\end{array}$} \\
\hline 対象外売上上位50成分 & 0.597 & 0.144 & $0.049^{* *}$ \\
\hline 対象外売上上位 100 成分 & 0.355 & $0.073^{*}$ & $0.012^{* *}$ \\
\hline$\frac{91 \text { 年1月制度対象成分 v.s. }}{\text { 制度対象外成分: 1992年 }}$ & & & \\
\hline 対象外売上上位50成分 & 0.540 & 0.191 & $0.007^{* *}$ \\
\hline 対象外売上上位 100 成分 & 0.269 & $0.081^{*}$ & $0.000^{* *}$ \\
\hline
\end{tabular}

注1: **(*)は5\%(10\%) 水準で有意な差がないという帰無仮説を寨却する。

注2: 2つの標本の分散は等しくないと仮定した。

注3: Arzneiverordnungs-Report (1989-92)より算出。

注4：91年1月の制度対象成分のうち、91年に売上を約650\%増やした

Troxerutinは分析から除いた。

ほどの影響はなかったと考えられる。

ここで，注目すべき点は，89年に制度対象になっ た成分の売上のみならず，90年 7 月，91年 1 月に 制度対象になった成分の売上にも参照価格制度の 一時的なマイナスの影響が見られるということで ある。したがって，むし89年における楽剤費上昇 抑制が参照価格制度導入によるあのであるとすれ ば，なぜ90年以降は薬剤費の上昇抑制が観察され ないのかという疑問が提起される。

\section{3. 参照価格制度の薬剂費上昇抑制効果}

前節では，参照価格制度が制度対象成分の売上 に一時的にマイナスの影響を与えることが示され た。この節では，薬剤費総額の上昇を抑制するほ
ど効果的であったかどうかを，89年とそれ以降に 分けて考察する。

公的医療保険に扮ける医薬品の売上高の伸びは, 89年こそ抑えられたものの，その後は以前と同様 かそれ以上に上昇している（表 5 参照）。したがっ て，少なくとも90年以降において，参照何格制度 は薬剂費上昇を抑制するには效果的ではなかった と考えられる。

（1）参照価格制度と89年における一時的な薬剤費 上昇の鈍化

以下では，89年の一時的な薬剂費上昇抑制が， 参照洒格制度の導入によるものかどうか検討する。 89年の売上高伸び率 $0.4 \%$ の内訳を見ると, 89 年 に参照価格制度の対象になった医薬品グループの 
旧西ドイッの参照価格制度と一時的楽剂費上昇抑制効果

表 5 公的医療保険における医薬品の売上高および処方量の推移と要因分解（旧西ドイッ）

\begin{tabular}{|c|c|c|c|c|}
\hline & $\begin{array}{l}\text { 売上総額 } \\
(10 \text { 億DM) }\end{array}$ & $\begin{array}{l}\text { 売上総額変化率 } \\
\text { (対前年比、\%) }\end{array}$ & $\begin{array}{l}\text { うち、処方量変化 } \\
\text { 要因 }(\%)\end{array}$ & $\begin{array}{l}\text { うち、処方 } 1 \text { 回 } \\
\text { 当たりの価格変化 } \\
\text { 要因 }(\%)\end{array}$ \\
\hline 1984 & 16.1 & 7.4 & -1.6 & 9.2 \\
\hline 1985 & 16.9 & 5.3 & 0.4 & 4.9 \\
\hline 1986 & 17.7 & 4.9 & 3.3 & 1.6 \\
\hline 1987 & 19.0 & 6.8 & 3.7 & 3.0 \\
\hline 1988 & 20.6 & 8.5 & 4.1 & 4.2 \\
\hline 1989 & 20.7 & 0.4 & -3.5 & 4.1 \\
\hline 1990 & 22.0 & 6.5 & 5.3 & 1.1 \\
\hline 1991 & 24.4 & 10.8 & 3.8 & 6.7 \\
\hline 1992 & 26.8 & 9.8 & 3.2 & 6.3 \\
\hline
\end{tabular}

\begin{tabular}{|l|ccc|}
\cline { 2 - 4 } \multicolumn{1}{c|}{} & $\begin{array}{c}\text { 全処方量 } \\
\text { (百万件) }\end{array}$ & $\begin{array}{c}\text { 全処方量変化幅 } \\
\text { (対前年比、百万件) }\end{array}$ & $\begin{array}{c}\text { 全処方量変化率 } \\
\text { (対前年比、\%) }\end{array}$ \\
\hline 1984 & 651 & -11 & -1.7 \\
1985 & 654 & 3 & 0.5 \\
1986 & 675 & 21 & 3.2 \\
1987 & 700 & 25 & 3.7 \\
1988 & 729 & 29 & 4.2 \\
1989 & 704 & -25 & -3.5 \\
1990 & 741 & 38 & 5.3 \\
1991 & 770 & 28 & 3.8 \\
1992 & 795 & 25 & 3.2 \\
\hline
\end{tabular}

注1: Arzneiverordnungs-Report (1994)より作成。

注2：処方量要因がマイナスの場合、処方量が減少したことを示す。

売上合計は，約 2 億マルク（対前年比10.6\%）低 下した（表6 参照）。全体の伸び率に対する寄与 度はおよそマイナス $1 \%$ になる ${ }^{\text {i:16) }}$

しかし, 以下の 4 つの理由から, 参照価格制度 が89年の一時的な薬剤費上昇抑制に殆ど寄与して いないことが示唆される。

- 理由 1 ：89年における参照価格制度の対象外医 薬品の処方量減少

89年に観察された楽剤費上昇の抑制は，全医 薬品の処方量減少によるところが大きい。ドイ ツ医薬品処方についての報告書であるArzneiverordnungs-Report（1990）によれば, 同年 売上総額の上昇率 $0.4 \%$ を要因分解した場合，

注16）すなわち，その低下幅は88年の総売上の約 $1 \%$ に相当する。一方, 参照価格制度対象外医薬品 の総売上は上昇している。全体の伸び率に対す る寄与度はプラス $1.5 \%$ にな。
処方量減少要因でマイナス $3.5 \%$, 処方 1 回当 たりの価格上昇要因でプラス $4.1 \%$ あっった (表 5 参照)。

この処方量減少には, 制度対象外医楽品の処 方量減少が大きく貢献している。同年に, 旧西 ドイッ全体の薬剂処方量が約2,520万回減少 （対前年比3.5\%減少）し，制度の対象になった 医薬品の処方量合計は約375万回減少（対前年 比5.6\%減少）した（表 5, 表 6 参照）。つまり， 制度の対象になっていない医楽品の処方量は 2,100万回以上減少した。制度の対象になって いる医薬品の処方量減少が全体の処方量減少に 占める割合は $15 \%$ 弱に過ぎない。

以上のことから，89年に観察された楽剤費上 昇抑制の主要因は参照価格制度の対象になって いない医薬品の処方量減少であることがわかる。 これまで, 参照洒格制度導入が制度対象外の医 
表 6 89年制度対象医薬品の売上・処方量合計と变化率（旧西ドイッ）

\begin{tabular}{|c|ccccc|}
\cline { 2 - 6 } \multicolumn{1}{c|}{} & $\begin{array}{c}\text { 売上 } \\
\text { (百万DM) }\end{array}$ & $\begin{array}{c}\text { 売上変化率 } \\
\text { (対前年比, \%) }\end{array}$ & $\begin{array}{c}\text { 処方量 } \\
(\text { 千件) }\end{array}$ & $\begin{array}{c}\text { 処方量変化率 } \\
\text { (対前年比、\%) }\end{array}$ & $\begin{array}{c}\text { 処方量変化幅 } \\
\text { (対前年比、千件) }\end{array}$ \\
\hline 1988 & 2,016 & 9.5 & 67,092 & 7.9 & 4,927 \\
1989 & 1,804 & -10.6 & 63,347 & -5.6 & $-3,745$ \\
1990 & 1,563 & -13.4 & 65,262 & 3.0 & 1,915 \\
1991 & 1,762 & 12.8 & 67,807 & 3.9 & 2,545 \\
1992 & 1,810 & 2.7 & 69,436 & 2.4 & 1,629 \\
\hline
\end{tabular}

注: Arzneiverordnungs-Report (1988-1993)より作成。

薬品の処方量を減少させることについての説得 的な説明は見られない。

制度対象外医楽品の処方量の減少が参照価格 制度以外の要因で引き起こされたならば，それ らの要因のいくつかが制度刘象になった医薬品 の処方量減少にも同時に貢献したことが考えら れる(i17)。したがって, 制度対象医薬品の炕方 量減少がすべて参照価格制度導入の影響である とは言い難い。前節の分析では, 参照価格制度 が制度対象成分の処方量に影響を与えたという 明確な結果は得られなかった。以上のことから， 89年に怙ける制度対象成分の売上低下には，参 照価格制度以外の要因も貢献していることがう かがえる。

- 理由 $2 ： 89$ 年 9 月に参照価格制度が実施される 以前の薬剤費の大幅な落ち込み

89年において参照価格制度が実施されたのは 9 月である。その 9 月以前に, 公的医療保険に おける医薬品の売上高が大幅に低下し，89年の 薬剤費上昇抑制に寄与した。表 7 には，88年第 4 四半期から89年末まで四半期ごとの売上高と その変化率（対前四半期比）が示されている。 参照価格制度の実施以前の89年第 1 四半期に売 上高が 88 年第 4 四半期比で $17.2 \%$ 減少してい る注18)。また, 制度実施後の第 4 四半期に薬剂 費が上昇している。

注17）医楽品の処方量の減少をあたらした要因に関し ては後で議論される。
- 理由 $3 ： 89$ 年において参照㑜格制度の実施され た期間は 4 か力足らず

89年の最初の 8 か月間は, 参照佂格制度が実 施されていない。つまり，89年に制度対象になっ た医楽品グループに対して，その制度の影響が 現れたのは89年の最後の 4 か月足らずである。 表 8 は，制度対象医薬品の洒格低下が制度実施 の9月から始まったことを示している。

その影響の多くは90年に現れた。90年になっ て処方 1 回当たりの価格の低下率は拡大してい る(図 3 参照)。そして，89年に対象になった 医薬品グループの売上合計は，90年にも対前年 比13.4\%低下した（表 6 参照）。図 4 は，その 売上低下の要因はその価格低下であることを示 している济199。むしろ, 処方 1 回当たりの価格

注18） 89 年第 1 四半期の売上低下は，9月に実施され た参照価格制度前の在庫調整という可能性があ る。医療機関が制度導入により制度対象の医薬 品の価格が低下すると予想すれば，制度実施前 になるべく在庫を減らそうとすることは合理的 な行動である。制度導入前に高い価格で医薬品 を仕入れて, 制度導入後にその值下げされた医 薬品を処方すれば，その差額分だけ医療機関に とって損になるからである。しかし，第 1 四半 期は 9 月より半年以上む前であることから，そ の可能性は低いと考えられる。

注19）図 4 における売上変化率, 処方 1 回当たりの価 格変化要因，売上変化要因は，各成分のそれぞ れの値を単純平均して算出した。各成分の売上 高の違いを考慮に入れても，同様の結果が得ら れる。 
表 788 年 89 年の四半期ごとの売上とその変化率（旧西ドイッ）

\begin{tabular}{|l|cc|}
\cline { 2 - 3 } \multicolumn{1}{l|}{} & $\begin{array}{l}\text { 売上 } \\
\text { (百万DM) }\end{array}$ & $\begin{array}{l}\text { 変化率 } \\
\text { (対前四半期比、\%) }\end{array}$ \\
\hline 1988年第4四半期 & 5,699 & 13.4 \\
& & \\
1988年計 & 20,568 & (対前年比8.5\%上昇) \\
\hline 1989年第1四半期 & 4,719 & -17.2 \\
1989年第2四半期 & 5,163 & 9.4 \\
1989年第3四半期 & 5,142 & -0.4 \\
1989年第4四半期 & 5,635 & 6.9 \\
1989年計 & 20,659 & (対前年比0.4\%上昇) \\
\hline
\end{tabular}

注：Scrip(1990)とArzneiverordnungs-Report(1990)より作成。

表 8 89年における医薬品価格の変化率（旧西ドイツ） （月次デー夕、対前年同月比、\%)

\begin{tabular}{|r|cc|}
\cline { 2 - 3 } \multicolumn{1}{c|}{} & $\begin{array}{c}\text { 参照価格制度 } \\
\text { 対象医薬品 }\end{array}$ & $\begin{array}{c}\text { 参照価格制度 } \\
\text { 対象外医薬品 }\end{array}$ \\
\hline 1月 & 0.3 & 1.9 \\
2月 & 0.4 & 2.0 \\
3月 & 0.3 & 1.7 \\
4月 & 0.1 & 1.8 \\
5月 & 0.1 & 1.8 \\
6月 & 0.1 & 1.8 \\
7月 & 0.1 & 1.8 \\
8月 & 0.1 & 1.9 \\
9月 & -14.6 & 2.1 \\
10月 & -15.5 & 2.2 \\
11月 & -15.6 & 2.2 \\
12月 & -15.8 & 2.2 \\
\hline
\end{tabular}

\section{制楾対象外医薬品の価整变化:}

1 8月 v.s. $9 \sim 12$ 月 有意確率 $($ 片側検定 $)=0.000$ ( $1 \%$ 水準で有意)

注 1：検定において、2つの標本の分散は等しくないと仮定した。

注2：価格変化率データはScrip(1990)より引用。

低下の売上高に対するマイナスの影響は89年に 比べ拡大している。

은 理由 $4: 89$ 年 9 月以降, 参照価格制度対象外医 薬品の補完的值上げの可能性

参照価格制度が導入された 9 月以降, 制度対 象外医楽品の価格上昇率が増加している（表 8 参照)。1 8月の価格上昇率の平均値之 9 〜 12月の同平均值に有意な差があるかどうか検定 したところ，有意な差はないという帰無仮説を $1 \%$ 水準で棄却した。このことから, 製薬企業
が制度対象医薬品の価格引き下げを補填するた め, 制度対象外医薬品の価格を引き上げた可能 性が指摘できる。この制度対象外医薬品の佂恪 引き上げは, 制度対象医薬品の価格引き下げの 薬剤費への影響を部分的に相殺する。また，89 年に抢ける制度対象外成分の売上増加に, 参照 価格制度が貢献していると考えられる。

以上の理由から，89年の参照価格制度導入が 薬剤費上昇を一時的に抑制させたという認識に は問題がある注20)。 
図 389 年 9 月 1 グループの加重平均価格指数の対前年変化率（旧西ドイッ）

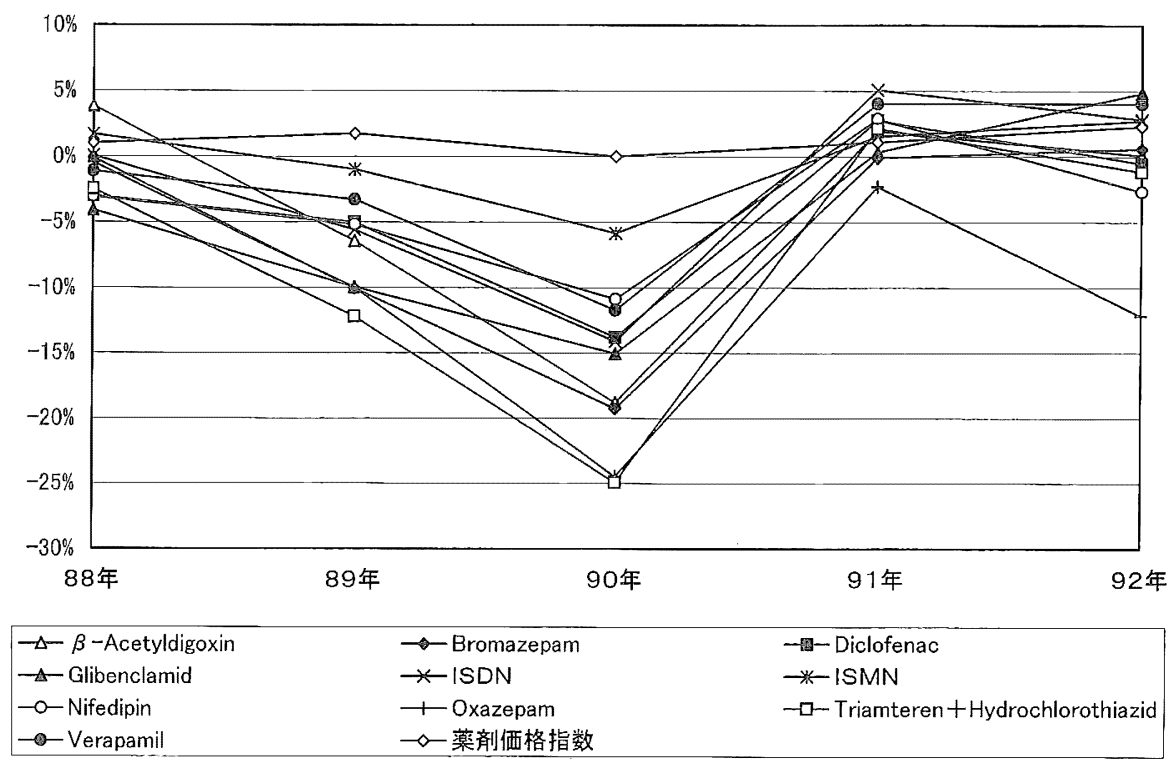

注 1: Arzneiverordnungs-Report(1988-1993)より作成。 注2: 平均価格指数は、各成分の売上を処方量で割って算出した。

注3:薬剤価格指数はPharma Daten(1995)に従う。その指数は参照価格制度の影響が含まれている。

\section{従来の説明}

参照価格制度が一時的に薬剂費上昇を抑制させ た理由としてこれまで説明されてきているのは, 短期的には参照価格を超える医薬品の使用が減少 する一方，長期的には参照洒格を下回る医薬品の 価格が上昇して参照価格に収束するということで

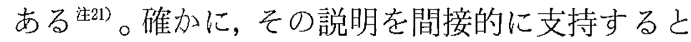
解釈可能なデータが存在しないことはない。例え ば，前述のように89年対象医薬品の処方量合計は 対前年比 375 万回減少 (対前年比 $5.6 \%$ 減少) した。 また，参照価格を下回る医薬品の約 $30 \%$ が90年ま

注20）また，89年以降む参照仙格制度対象品目が拡大 していることから，もし参照価格制度導入が一 時的な薬剂費上昇抑制に大きく寄与したならば, 制度対象医薬品の拡大と共に持続的な抑制効果 が見られるはずである。補論参照。

注21）例えば, Dickson and Redwood (1998), 铇 田・南部（1999）を参照。
でに価格を引き上げ，残りは価格を据え置い

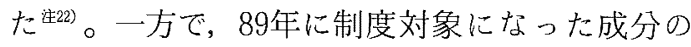
価格低下が一段落した91年には，その売上合計は 上昇に転じている（表 6 参照）。つまり，そのグ ループの総売上は89年から90年にかけて一時的に 低下した。

しかし，上記の 4 つの理由により，この一時的 な売上低下と89年に観察された薬剤費上昇鈍化を 直接結びつけることは問題である。また，その鈍 化が一時的でしかなかった理由に関しては，制度 対象医薬品で基準価格を下回る医薬品の価格上昇 の影響は相対的に小さいことが， Arzneiverordnungs-Report（1994）から推測できる。第1に, 90年から92年に扔いて薬剤費が上昇した要因とし て処方量の伸びが大きい（表 5 参照）。第 2 K, 91 年 1 月と 92 年末のデータを比較すると, 参照価

注22）鈴木・中村（1998）参照。 
図 4 89年 9 月 I グループの売上変化率の要因分析（旧西ドイツ）

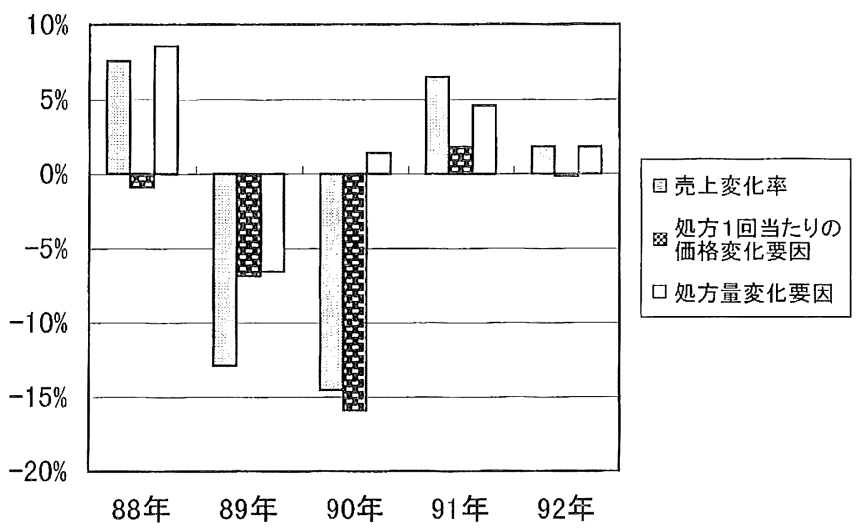

注： Arzneiverordnungs-Report(1988-1993)より作成。まず、各成分の売上を処方量で割り

処方 1 回当たりの価格を算出した。そして、各成分ごとに売上変化率を算出し、

処方1回当たりの価格変化による影響と処方量変化による影響に要因分析した。

最後に各成分のそれぞれの值を単純平均し、グラフ化した。

格制度対象医薬品の価格指数は1.6\%低下したこ とから，薬剤費上昇には貢献していない。

\section{（2） 89年に薬剤費の伸びが抑制された理由}

これまでの議論から，89年に薬剤費增加を抑制 した主要因として参照価格制度を考えることは困 難である。その抑制要因は同年 1 月から施行され た医療保険改革法（GR G）であることが考えら れるため，参照価格制度以外の改革を考察する必 要がある(:23)。薬剤費上昇抑制（特に，処方量抑 制）に影響を与えたと考えられる制度改革は以下 のとおりである。

- 参照価格制度対象外医薬品の自己負担額の引き 上げ：

参照価格制度対象外医薬品の自己負担額が 2 DMから 3 DMに引き上げられた。自己負担額 の増加が，過剩投薬を抑制し処方量抑制に寄与 したことは考えられる。また，参照洒格制度対 象医薬品屯制度が実施される 9 月以前には自己

注23）89年の医療保険改革法に関する詳細は，例えば 厚生省保険局企画課（1994）参照。
負担が発生したことから，この自己負担額引き 上げの影㗽を受けている。

百経済性審査:

医療機関と疾病金庫との折衝で，医療機関の 専門あるいは患者数および患者の年齢により四 半期ごとに平均処方量が算出され，この平均量 を超えると特に非経済的な医薬品使用に関して 医療機関に通知が行われる。またこの通知が効 果的でない場合，その医療機関はすべての経費 についての経済性審査が行われる。それでも改 善されなければ，超過経費は医療機関の負担と なる。この経済性審査と超過費用の負担を避け るため, 各医療機関が処方量を減少させたこと は考えられる。例えば, ArzneiverordnungsReport（1990）によると，当時有効性に疑問 があるとされた医薬品群の処方量および売上は, 89年には数年ぶりに減少した。減少幅はそれぞ れ対前年比3.7\%，4.7\%であった注24)。ただ， この効果も長続きしなかった。効果疑問薬の総

注24）89年における医薬品総売上の上昇率 $0.4 \%$ に対す る寄与度は抢よそマイナス $1.3 \%$ になる。 
売上は，90年以降G S Gが実施される93年まで， 毎年伸び続けた迅25)。

○薬剤師による薬剤代替調剂制度：

医師は薬剤師が同等の有效性でより低コスト な薬侴を患者に渡すことができるかどうかにつ いて，処方䈅に明記することを義務づけられた。 この制度改革は, 同等の有効性ならばより低価 格の医楽品への需要を高める。また, 同等の医 薬品間の洒格競争を促進する。

\section{先取り効果と一時的な薬剂費抑制効果}

上記の制度改革のうち自己負担増加之経済性審 查は, 医療保険改革法施行直前の88年第 4 四半期 に薬剤の駆込み需要をもたらし，その反動で89年 第 1 四半期の薬剤費が低下したと考えられる ${ }^{(226)}$ 。 表 7 は, 88年第 4 四半期に薬剤費総额が対前四半 期比で13.4\%上昇した後，89年第 1 四半期には同 期比で17.2\%低下したことを示している（理由 2 参照)。本来なら89年に入ってから処方されるべ き薬剂を施行直前に処方することは，患者にとっ て自己負担增の影響が軽減されることになる。ま た，医療機関にとって，89年の処方量減少につな がることから経済性審查の面から有利に働く。

また，この先取り效果は, 89年だけの特殊要因 である。したがって，その効果は，89年に観察さ れた薬剤費上昇鈍化がなぜ一時的であったかを， ある程度説明することが可能である ${ }^{(227,28) 。 ~}$

\section{（3） 90年から92年における薬剤費上昇}

89年以降にも参照佂格制度が㭗剂費上昇抑制に

注25）Arzneiverordnungs-Report（1991-94)参照。 90年には5.3\%，90年には7.8\%，90年には9.0\%， それぞれ上昇している。

注26) Arzneiverordnungs-Report (1990)参照。

注27）この研究の焦点は, 参照仙格制度と89年におけ る一時的な薬剂費鈍化の因果関係が小さいこと を検証することであるが，その一時性について の詳細な分析は, 今後必要である。
効果的でなかった理由として，少なくとも以下の 4 点が指摘できる。第 1 に, 第 2 節の分析から, 参照価格制度が制度対象成分の処方量に明確な影 響を与えていないことが示唆される。第 2 に, Arzneiverordnungs-Report（1990～93）によれ ば，製薬企業は制度刘象外成分の価格を引き上げ ることで，制度対象成分で参照洒格を上回る医薬 品の值下げの影響をある程度相殺した。上記の分 析でも, 参照洒格制度導入後, 制度対象外成分の 価格上杽率が導入前に比べ上昇したことが明らか になった ${ }^{(29)}$ 。

第 3 に, 制度対象成分で参照価格を下回る医薬 品が值上げを行う傾向がある汇30)。第 4 K, 参照 価格制度は同等でない医薬品をグルーピングでき ないことから，その対象範囲には限界がある。し たがって，参照価格制度の影響が及ぶ範囲屯限定 される。薬業時報社編集局編（1998）によれば, 参照仙格制度対象品目の売上と処方量のマーケッ トシェアは97年 5 月において $60.4 \% ， 63.9 \%$ によ どまっている。

\section{4.まとめと留意点}

旧西ドイツにおいて参照価格制度は制度対象成

注28）日本においては，馬場園（1990）が日本のある 健康保険組合に属する高血圧症の患者を対象に 1984年の 1 割自己負担導入の受療摔への影響を 調べたところ，一侍的な受療抑制効果しかなかっ たと結諭づけた。また， 1 割自己負担導入前に 駆け込み受療が見られたことも指摘している。

注29) Arzneiverordnungs-Report（1990-92）は, 制度導入後に制度対象外成分の価格が上昇した ことを指摘したが, 制度導入前の制度対象外成 分の価格変化率とは比較していない。

注30）例えば，鈴木・中村（1989）参照。Arzneiverordnungs-Report（1990）によれば，89年に制 度対象になった成分で参照优格以下の医楽品は 89年中に殆ど值上げしなかった。しかし，鈴木・ 中村 (1989) は, その参照们格以下の医薬品の 約30\%が91年までに值上げしたことを指摘した。 
旧西ドイッの参照価格制度と一時的薬剂費上昇抑制効果

分の売上を一時的に有意に低下させた。しかし， その効果は89年においても薬剤費上昇を抑制する ほどの大きな効果はなかった。したがって，薬剤 費上昇が参照価格制度導入の89年に一時的に抑制 されたことを理由に，その一時的抑制が参照価格 制度の導入によって引き起こされたと結論づける ことには問題がある。

ただ，これまでの議論から，同等効果の医薬品 をグルーピングして同一保険償還価格をつけると いう参照価格制度の一つの本質的な考え方が薬剤 費の上昇抑制に効果がないと結論づけるのは早急 である。参照価格制度にはさまざまなタイプがあ り，ドイッ型制度を手直しすることで，その薬剤 費上昇抑制効果を高めることができるかもしれな い。例えば，デンマークでは，参照価格をグルー プ内医薬品の最低価格近傍に設定した。日本製薬 団体連合会（1997）は，その制度導入により一定 の削減効果があったというデンマーク薬剤師会の 発言を掲載している。また, 参照価格以下の医楽 品の価格上昇を制限することも薬剤費上昇抑制に は効果的であるかもしれない。したがって，薬剤 費上昇抑制をより効果的にする参照価格制度の在 り方について議論することは, 今後も重要である。

\section{参考文献}

Bundesverband der Pharmazeutischen Industrie e.V. Rote Liste '87-'93. Editio cantor.

Bundesverband der Pharmazeutischen Industrie e.V. (1995) Pharma Daten.

Dickson, M. and H. Redwood (1998) "Pharmaceutical Reference Prices : How do they Work in Practice?," PharmacoEconomics. 14 (5): 471-479.

Schwabe, U. and D. Paffrath ArzneiverordnungsReport '87-'94. Gustav Fischer Verlag.

Scrip (1989) No. 1382. United Kingdom : PJB Publications LTD.

Scrip (1991) Yearbook 1991. United Kingdom: PJB Publications LTD.

厚生省保険局企画課監修（1994）『欧米諸国の医療保障』
法研

鈴木雅人, 中村洋 (1998)「ドイッ型参照価格制度の個 別医療用医薬品価格・処方量と研究開発インセンティ ブへの影響」『医療之社会』8（3）: 17-38

铇田忠彦, 南部鶴彦（1999）「薬価上限制の導入断念を」 日本経済新聞『経済教室』2月3日

日本製薬団体連合会保険薬価研究委員会編（1995）『先 進諸国の薬剤給付・薬価制度? 海外調查団報告書』

日本製薬団体連合会（1997）「欧州参照洒格制度調查報 告」薬業時報社編集局編『薬価改革・日本型参照価 格制度』薬業時報社

馬場園明（1990）「一割負担導入の高血圧症患者に対す る影響」『日本衛生学雑誌』45

『ラージュ」1999年 5 月10日 薬業時報社

（1999年 7 月16日受付，1999年12月10日採用）

\section{補論}

89年に参照価格制度の対象となったのは10成分 であり，対象成分売上のマーケットシェアは 9.8 \%にしかすぎなかっだき31)。90年に扮ける制度対 象成分の増加数は33, 売上のマーケットシェアの 上昇幅は $11.6 \%$ であった。91年の制度対象成分の 増加数は54成分, 売上のマーケットシェアの上昇 幅は3.9\%であった。92年にもそれぞれの数值は 上昇している。

これらのデータから以下の 2 点が明らかである。 第 1 に，制度の対象になった医薬品は90年から92 年にかけて成分数，売上シェアの観点から確実に 桩大している。第 2 に，89年に対象になった医薬 品とその後に対象になった医薬品を比較すると， 前者の成分数, 売上シェアが後者のそれらの变数 に比べ格段に大きいとは言えない。

参照価格制度導入が89年の一時的な薬剤費上昇 の抑制に大きく貢献したならば，制度対象医薬品

注31）成分数に関しては日本製薬団体連合会保険薬価 研究委員会 (1995) 参照。マーケットシェアは 日本製薬団体連合会 (1997), Arzneiverordnungs-Report（1990 1994）汃ら作成。以下 の数字屯同様。 
医療と社会 Vol.9 No.4 1999

の拡大ととあに持続的な抑制効果が見られるはず である。なぜなら，新たに制度対象になった医薬 品は一時的にしか薬剂費上昇抑制に貢献しないす のの, 年々制度対象医薬品が拡大することで抑制 効果は持続するからである。しかし，表 5 から明 らかなように，89年に見られたような薬剤費上昇 の鈍化はその後観察されていない。 


\title{
The Temporary Lowering Effects of West Germary's \\ Reference Pricing System on Rising Pharmaceutical Expenditure : Did the System Contribute to the Temporary Slowdown in 1989 ?
}

\author{
Hiroshi Nakamura*, Ph. D.
}

\begin{abstract}
In West Germany, the growth of pharmaceutical expenditure was temporarily constrained in 1989 when the reference pricing system was introduced. From this fact, it is argued that the lowering effect of the reference price system on pharmaceutical expenditure is "once-for-all." This paper examines the effects of the system on the sales of each individual ethical ingredient to assertain the existence of the "once-for-all" lowering effect on each individual ingredient's sales. However, the paper also shows that the reference pricing system had played merely a minor role in constraining the growth of pharmaceutical expenditure in West Germany.
\end{abstract}

Keywords: Reference pricing system, "Once-for-all" lowering effect on pharmaceutical expenditure, Individual ingredient's sales

* Graduate School of Business Administration, Keio University 